\title{
Możliwości zastosowania skaningowej mikroskopii akustycznej do analizy jakości połączeń spajanych
}

\author{
Possibilities of applying of scanning acoustic microscopy \\ for quality evaluation of bonding joints
}

\section{Streszczenie}

W artykule przedstawiono możliwości zastosowania mikroskopii akustycznej do oceny jakości złączy spajanych. Scharakteryzowano ideę działania mikroskopii akustycznej i wskazano jej zalety w porównaniu z innymi nieniszczącymi technikami badawczymi. Opisano funkcjonalność stosowanego do badań mikroskopu OKOS i przedstawiono możliwości badawcze w zakresie kontroli jakości połączeń spajanych. $Z$ jego wykorzystaniem analizowano złącza klejowe, lutowane, zgrzewane rezystancyjnie punktowo, spawane metodą MAG, spawane wiązką lasera, złącza doczołowe rurowe zgrzewane łukiem wirującym oraz powłoki natryskiwane metodą Cold Spray. Przedstawiono wyniki badań ultradźwiękowych połączeń za pomocą różnych sposobów zobrazowania (B-skan, C-skan), szczególnie w aspekcie badań połączeń cienkościennych.

Słowa kluczowe: skaningowa mikroskopia akustyczna; badania nieniszczące; kontrola jakości złączy spajanych

\begin{abstract}
The article presents the possibilities of using scanning acoustic microscopy (SAM) for quality evaluation of joints made by selected welding methods. The concept of acoustic microscopy has been characterized and its advantages compared to other non-destructive testing techniques have been described. The functionality of the OKOS microscope and its potential for quality evaluation of welded joints has been presented. Adhesive, soldered, spot welded, MAG welded, laser welded joints, pipe butt MIAB welded and Cold Sprayed layers have been tested and analyzed by SAM. The results of ultrasonic examination of the selected joints have been presented in different ways of ultrasonic visualization (B-scan, C-scan), especially in the aspect of thin-wall tests.
\end{abstract}

Keywords: scanning acoustic microscopy; nondestructive testing; quality evaluation of bonded joints

\section{Wprowadzenie - postęp w nowoczesnych, ultradźwiękowych badaniach nieniszczących}

Zastosowanie badań ultradźwiękowych do oceny złączy spajanych znane jest od dziesięcioleci. Najbardziej popularnym sposobem wykorzystania fal ultradźwiękowych jest zastosowanie pojedynczego przetwornika, pracującego naprzemiennie jako nadajnik i odbiornik w trybie tzw. metody echa, lub dwóch przetworników, z których jeden jest nadajnikiem, a drugi odbiornikiem - tzw. metoda transmisyjna (przepuszczania). Konieczność detekcji coraz mniejszych niezgodności implikuje ciągłą modyfikację tych technik, zarówno poprzez zastosowanie coraz wyższych częstotliwości fal ultradźwiękowych, impulsów o możliwie krótkim czasie trwania, jak również wykorzystanie zjawisk fizyko-akustycznych (dyfrakcja, transformacja fali na granicy ośrodków, interferencja fal w polu ultradźwiękowym), dzięki którym z jednej pozycji umieszczenia głowicy możliwa jest detekcja niezgodności zorientowanych pod różnymi kątami w stosunku do kierunku padania fali ultradźwiękowych.

Jedną z technik, wykorzystującą dyfrakcję fali ultradźwiękowej na krawędziach niezgodności jest metoda TOFD (ang. Time of Flight Diffraction) [1]. Polega ona na wykorzystaniu dwóch współpracujących ze sobą głowic kątowych w układzie nadajnik - odbiornik, które umieszczone są na tej samej powierzchni badanego obiektu (wymagany jednostronny dostęp), a między nimi znajduje się obszar badany

Dr inż. Marcin Korzeniowski, dr inż. Tomasz Piwowarczyk - Politechnika Wrocławska.

Autor korespondencyjny/Corresponding author: tomasz.piwowarczyk@pwr.edu.pl 
(np. spoina). Istotą metody jest interpretacja sygnału na podstawie porównania czasów odebrania składowych fali. W przypadku, gdy w materiale nie występuje nieciągłość, odbierane są dwie składowe - amplituda fali powierzchniowej i fali poprzecznej odbitej od dna badanego materiału. Na tej podstawie można określić grubość przedmiotu. Kiedy w badanym obszarze wystąpi nieciągłość, na jej krawędziach (górnej i dolnej) fala ultradźwiękowa ulega dyfrakcji. Pomiar czasu dotarcia ech dyfrakcyjnych, czasu dotarcia fali powierzchniowej oraz fali odbitej od dna, pozwala na podstawie zależności trygonometrycznych określić z dużą dokładnością wymiary i głębokość występowania niezgodności [1].

Większość współczesnych głowic ultradźwiękowych to elementy jednoprzetwornikowe. Emitują one fale w jednym kierunku uwarunkowanym specyfiką i rodzajem głowicy. Ruch skanujący (ręczny lub automatyczny) polega na przemieszczaniu głowicy po interesującym obszarze, w wyniku czego powstaje obraz składający się z n-punktów pomiarowych. Taki typ badania jest najczęściej czasochłonny. Inną możliwością, umożliwiającą badania relatywnie większego obszaru materiału jest zastosowanie urządzeń do badań techniką PA (ang. Phased Array), w których podstawowym elementem jest głowica wieloprzetwornikowa (najczęściej składająca się od 16 do 128 elementów) [2]. Kompletne urządzenie składa się z generatora, który emituje sygnał elektryczny o parametrach tożsamych z parametrami wiązki ultradźwiękowej wytwarzanej w wyniku drgań pojedynczego przetwornika. Każdy z przetworników jest sterowany niezależnie za pomocą elementów opóźniających, które z kolei kontrolowane są przez układ mikroprocesorowy. Interferencja fal w polu ultradźwiękowym (wzajemne wzmacnianie lub wygaszanie fali w różnych punktach przestrzeni) daje możliwość wytworzenia wiązki o pożądanym kształcie np. konkretnym kącie załamania, wiązki zogniskowanej lub przemiatającej - o zmiennym w czasie kącie załamania [3]. Czoła fali pochodzące od poszczególnych przetworników są sferyczne i zgodnie z zasadą superpozycji tworzą wypadkową falę przemieszczającą się w specyficznym kierunku. Kontrolowane sterowanie opóźnieniem generowania pojedynczej fali na poszczególnych przetwornikach skutkuje emisją fali nachylonej pod odpowiednim kątem.

Oprócz wykorzystania zjawisk fizyko-akustycznych niewątpliwym ułatwieniem badań ultradźwiękowych jest zastosowanie skanerów. Znane są skanery manualne, półautomatyczne, w których układ pomiarowy zintegrowany z defektoskopem ultradźwiękowym jest w stanie lokalizować pozycję głowicy, przez co możliwe jest mapowanie badanego obszaru. Skanery wyposażone są w czujniki pozwalające na przeliczanie ich sygnałów na aktualną pozycję urządzenia. Najczęstszym rozwiązaniem jest zastosowanie enkoderów zliczających liczbę obrotów kół skanera. Skanery manualne, podobnie jak same głowice manualne, są kontrolowane za pomocą ruchu dłoni operatora. Umożliwiają prowadzenie głowicy lub układu głowic z większą precyzją, przez co otwierają możliwości praktycznego wykorzystania zaawansowanych technik. Jednym z najbardziej perspektywicznych rozwiązań jest badanie za pomocą zintegrowanych technik TOFD + PA. Obie te techniki wzajemnie się uzupełniają i umożliwiają uzyskanie najbardziej wiarygodnych i dokładnych wyników [4].

\section{Skaningowa mikroskopia akustyczna}

Pomimo niewątpliwych zalet metod TOFD i PA do oceny jakości złączy spajanych ich zastosowanie ogranicza się zwykle do konstrukcji o znacznych grubościach ścian$\mathrm{ki}$. Jest to związane z częstotliwościami fal generowanych przez przetworniki. Dla metody TOFT jest to $15 \mathrm{MHz}$, a dla PA - $10 \mathrm{MHz}$ [4]. W praktyce oznacza to ich zastosowanie dla minimalnej grubości wynoszącej ok. $5 \mathrm{~mm}$. Dla konstrukcji cienkościennych o grubości ścianki poniżej $2 \mathrm{~mm}$, w przypadku metody echa konieczne jest zastosowanie przetworników o znacznie wyższych częstotliwościach (od 20 do $100 \mathrm{MHz}$ ). Technika ultradźwiękowa polegająca na wzajemnym sprzężeniu przetwornika wysokiej częstotliwości z ogniskowaniem wiązki, układu pozycjonującego (skanera) i generatora fal ultradźwiękowych nosi nazwę skaningowej mikroskopii akustycznej (ang. Scanning Acoustic Microscopy SAM) i skutecznie eliminuje wspomniane ograniczenia, umożliwiając prowadzenie badań ultradźwiękowych dla cienkich blach (poniżej $3 \mathrm{~mm}$ ). Rozdzielczość mikroskopu ultradźwiękowego zależy w znaczącej mierze od częstotliwości stosowanych fal akustycznych oraz od parametrów układu ogniskującego (apertury numerycznej). Dlatego w celu uzyskania rozdzielczości na poziomie mikrometrów stosuje się fale o częstotliwościach powyżej $200 \mathrm{MHz}$, a nawet rzędu kilku gigaherców [5,6]. Przy doborze częstotliwości fali należy jednak brać pod uwagę również zależność tłumienia fali w materiale od częstotliwości. Dla wysokich częstotliwości maleje bowiem możliwa głębokość penetracji fali ultradźwiękowej w materiale próbki, z racji wzrostu współczynnika absorbcji [5]. Zastosowanie soczewek akustycznych w konstrukcji przetwornika wymusza ich wklęsły kształt, co $\mathrm{w}$ przypadku badań z zastosowaniem mikroskopii akustycznej implikuje najczęściej zastosowanie metody immersyjnej (zanurzeniowej). Jako ciecz sprzęgająca najczęściej stosowana jest woda z dodatkiem inhibitorów korozji.

Najważniejszym elementem mikroskopu akustycznego, oprócz generatora odpowiednio krótkich impulsów, jest układ ogniskujący przetwornika. Odpowiednia konstrukcja soczewki akustycznej umożliwia uzyskanie bardzo dobrej rozdzielczości wzdłuż osi równoległej do kierunku rozchodzenia się fali. Fala dźwiękowa po przejściu przez układ ogniskujący jest transmitowana do ośrodka pośredniczącego o dużej impedancji akustycznej (zazwyczaj jest nim woda), dzięki czemu w wyniku dużej różnicy prędkości rozchodzenia się fali w obu ośrodkach, kąt załamania na granicy ośrodków jest niewielki, co ogranicza występowanie aberracji [5]. Soczewka akustyczna ma zazwyczaj postać dysku wykonanego z monokrystalicznego szafiru, o osi symetrii równoległej do osi krystalograficznej $c$, z jedną z powierzchni czołowych uformowaną w kształt wklęsłej czaszy sferycznej [6]. Skaningowa mikroskopia akustyczna znalazła szerokie zastosowanie w układach diagnostycznych (szczególnie diagnostyki powierzchni, badaniach własności materiałowych

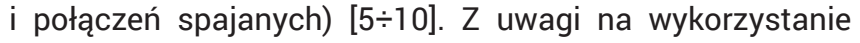
jednego przetwornika piezoelektrycznego do detekcji i generacji, fala akustyczna generowana jest w postaci impulsu. Zasada działania skaningowego mikroskopu akustycznego została przedstawiona schematycznie na rysunku 1.

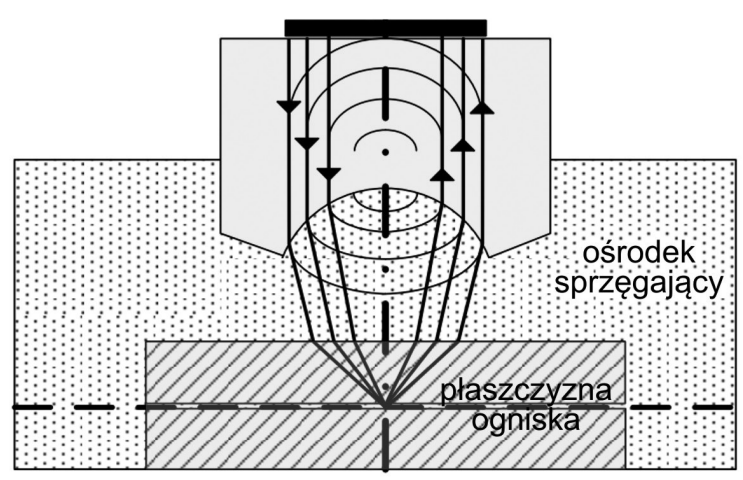

Rys. 1. Układ ogniskujący przetwornika

Fig. 1. Transducer focusing system 


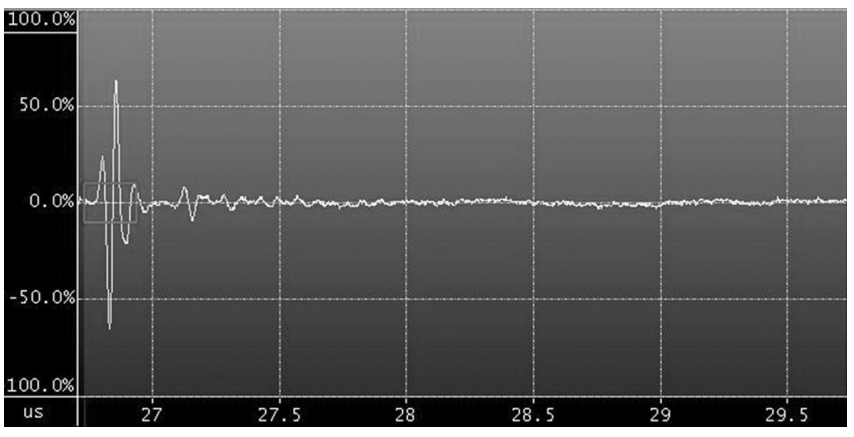

Rys. 2. Przykładowa prezentacja A-skan sygnału ultradźwiękowego Fig. 2. Example presentation of A-scan ultrasonic signal

Podczas skanowania głowica jest przemieszczana w obrębie zadanego obszaru w osiach prostopadłych do kierunku rozchodzenia się fali po punktach wyznaczonych przez system sterowania w zależności od określonej rozdzielczości. W każdym punkcie emitowany jest krótki impuls dźwiękowy i mierzona odpowiedź napięciowa przetwornika piezoelektrycznego pod wpływem wracających fal odbitych na granicach ośrodków. Przetworzony przebieg amplitudy fali w czasie określany jest jako A-skan (rys. 2).

Bardziej użyteczny w analizie jest jednak tak zwany B-skan, stanowiący zbiór A-skanów zebranych z punktów wzdłuż linii prostej, zrzutowanych na płaszczyznę. B-skan ma najczęściej formę dwuwymiarowej mapy w skali szarości, w której oś odciętych odpowiada liniowemu przesunięciu wzdłuż osi prostopadłej do kierunku rozchodzenia się fali, a oś rzędnych czasowi rozchodzenia się fali w materiale. Odcień w skali szarości odpowiada amplitudzie zarejestrowanej fali [11].

Na rysunku 3a przedstawiono poglądowy rysunek obrazujący płaszczyznę B-skan wzdłuż wybranej linii przekroju. Wartości amplitudy dla określonego przesunięcia czasowego, na przykład odpowiadającego odbiciu od powierzchni styku dwóch elementów, mogą zostać zrzutowane na płaszczyznę odpowiadającą obszarowi skanowania. W ten sposób otrzymuje się mapę w skali szarości, gdzie odcienie odpowiadają maksymalnej amplitudzie zarejestrowanego sygnału lub czasowi akwizycji sygnału [11]. Ten sposób zobrazowania nosi nazwę C-skan (rys. 3b).

Rzeczywiste prezentacje C-skan oraz B-skan (w 2 płaszczyznach prostopadłych do powierzchni) przedstawiono na przykładzie blachy ze stopu aluminium o grubości $1 \mathrm{~mm}$ z nawierconymi otworami przelotowymi o różnych średnicach

a)

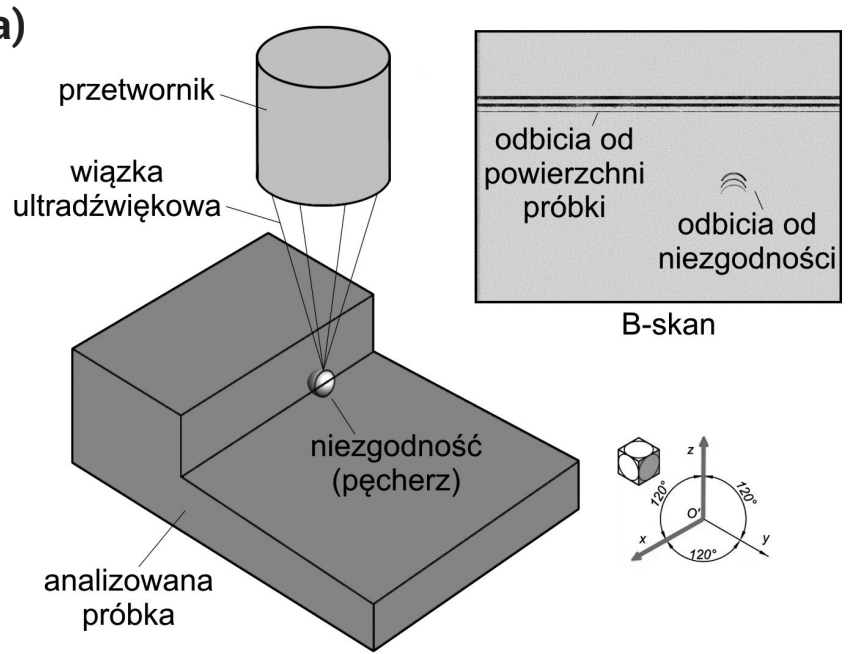

(rys. 4). Skala szarości reprezentuje amplitudę fali w określonym punkcie przestrzeni (w przypadku badanej próbki jest to jej powierzchnia), a w miejscach, w których występują otwory nie jest rejestrowane odbicie, zatem obszary te rozpoznawane są jako nieciągłość.

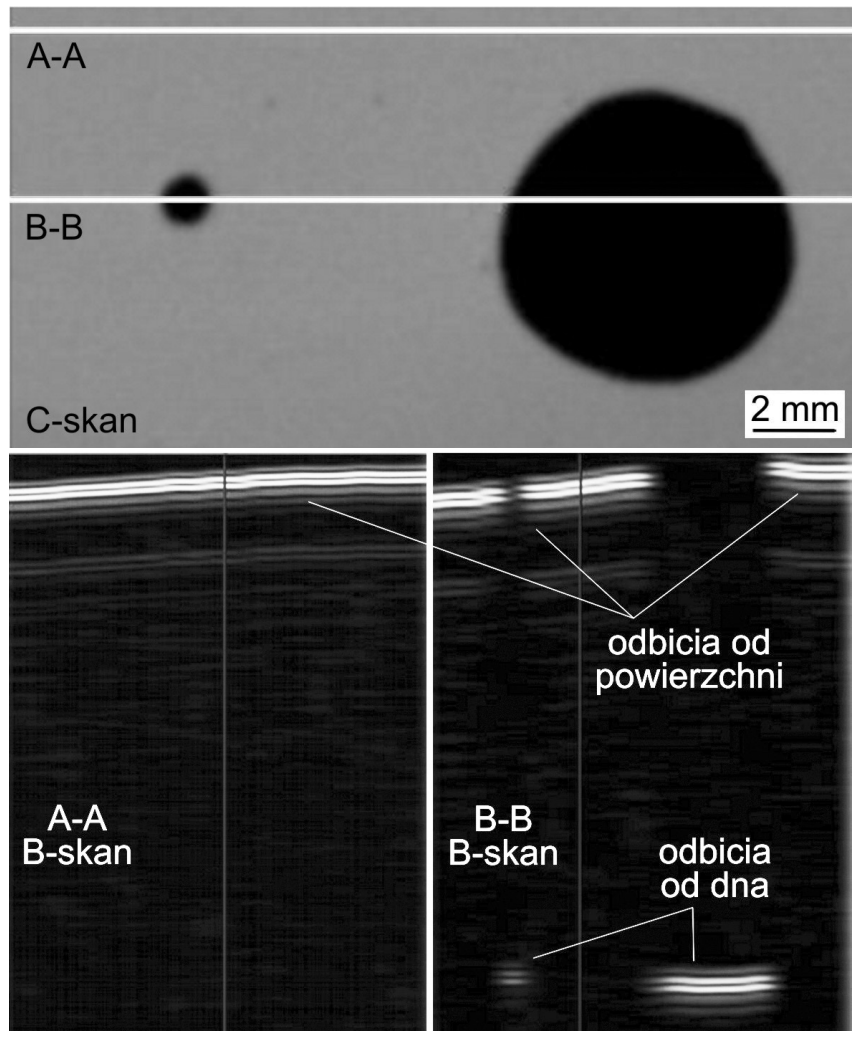

Rys. 4. Przykładowa prezentacja C-skan wraz z przekrojami w dwóch płaszczyznach (B-skan)

Fig. 4. Sample $\mathrm{C}$-scan presentation with two-plane cross-sections (B-scan)

\section{Mikroskop akustyczny wykorzystany do badań}

Badania wybranych złączy spajanych przeprowadzono z wykorzystaniem skaningowego mikroskopu akustycznego OKOS NDTCF300 (rys. 5), wyposażonego w 3 osiowy manipulator kartezjański, którego obszar roboczy na płaszczyźnie (w osiach $x-y$ ) ograniczony jest w zakresie 450x450 mm,

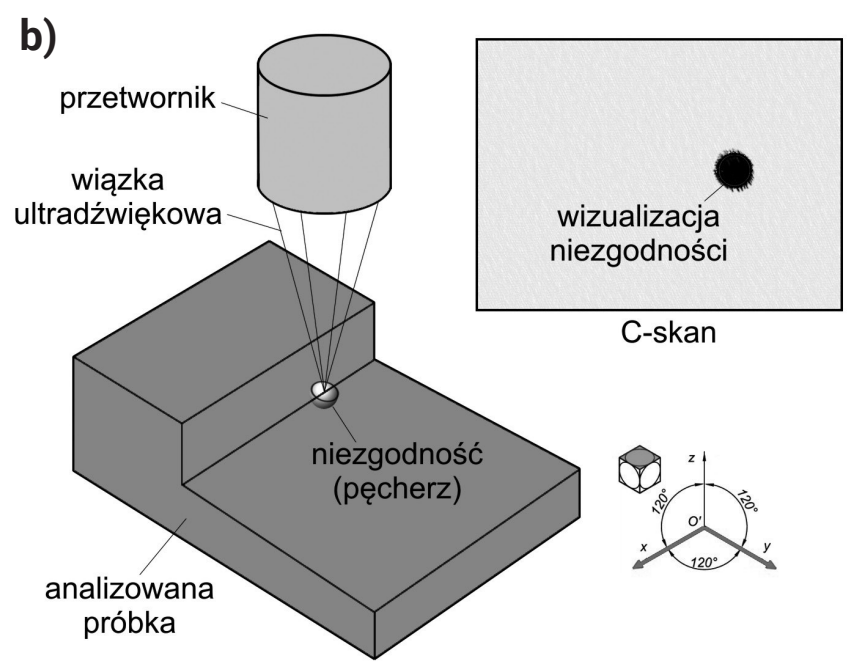

Rys. 3. Sposoby wizualizacji sygnału ultradźwiękowego: a) prezentacja B-skan, b) prezentacja C-skan

Fig. 3. TVisualization methods of ultrasonic signal: a) B-scan presentation, b) C-scan presentation 


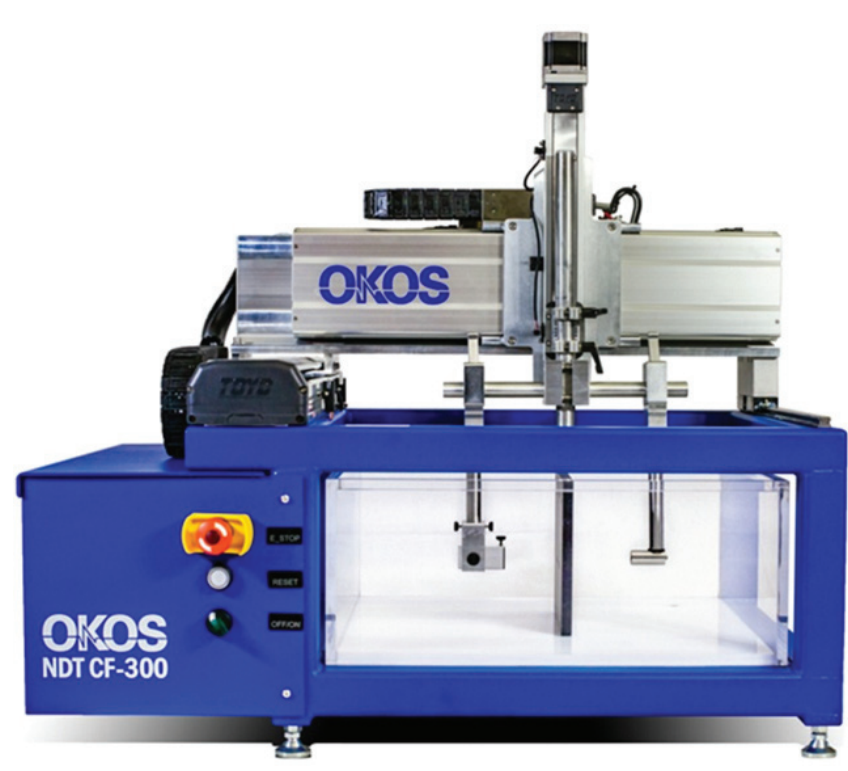

Rys. 5. Mikroskop akustyczny OKOS NDTCF300 wykorzystany do badań

Fig. 5. OKOS NDTCF300 acoustic microscope used for research

a jego maksymalna dokładność pozycjonowania osi x-y wynosi $1 \mu \mathrm{m}$. Oś "z" wykorzystywana jest wyłącznie do ogniskowania wiązki i pozostaje nieruchoma podczas skanowania. Układ przetwarzania sygnału ultradźwiękowego składa się z nadajnika-odbiornika połączonego z kartą akwizycji sygnału o częstotliwości próbkowania $1 \mathrm{GHz}$. Pomiary przeprowadzono wykorzystując przetwornik o średnicy $8 \mathrm{~mm}$, częstotliwości środkowej $20 \mathrm{MHz}$ i długości ogniska w wodzie $15 \mathrm{~mm}$ (średnica ogniska $1 \mathrm{~mm}$ ). Rozdzielczość pomiarowa w osiach $\mathrm{x}-\mathrm{y}$ wynosiła $50 \mu \mathrm{m}$.

\section{Kontrola SAM złączy spawanych metodą MAG}

Jako przykład zastosowania skaningowej mikroskopii akustycznej do analizy złączy spawanych wybrano konstrukcję fotela samochodowego, a konkretnie połączenie panelu bocznego z nakrętką, w którą wkręcone są elementy usztywniające i zapewniające bezpieczeństwo osób podróżujących. Nakrętka M10 wykonana ze stali C10 połączona została obwodową spoiną pachwinową z blachą o grubości $1 \mathrm{~mm}$ ze stali walcowanej na zimno H420LA. Proces spawania przeprowadzono w osłonie gazu aktywnego (mieszanka M21) różnymi odmianami metody MAG: CMT, MAG z prądem pulsującym oraz z wykorzystaniem klasycznego łuku zwarciowego. Na rysunku 6 przedstawiono prezentacje C-skan spoin wykonanych w wymienionych odmianach metody MAG. Pomiar przeprowadzono od strony blachy.

Z przeprowadzonych badań wynika, że najbardziej regularny przetop i kształt spoiny uzyskuje się poprzez wykorzystanie metody CMT (rys. 6c). Spoiny wykonane w odmianie MAG Puls charakteryzują się nieregularnym kształtem, miejscowymi brakami przetopu oraz relatywnie wąskim wtopieniem (rys. 6b). Dla spoiny wykonanej z użyciem łuku zwarciowego MAG (rys. 6a) zaobserwowano zmienną szerokość wtopienia na powierzchni styku nakrętka - blacha.
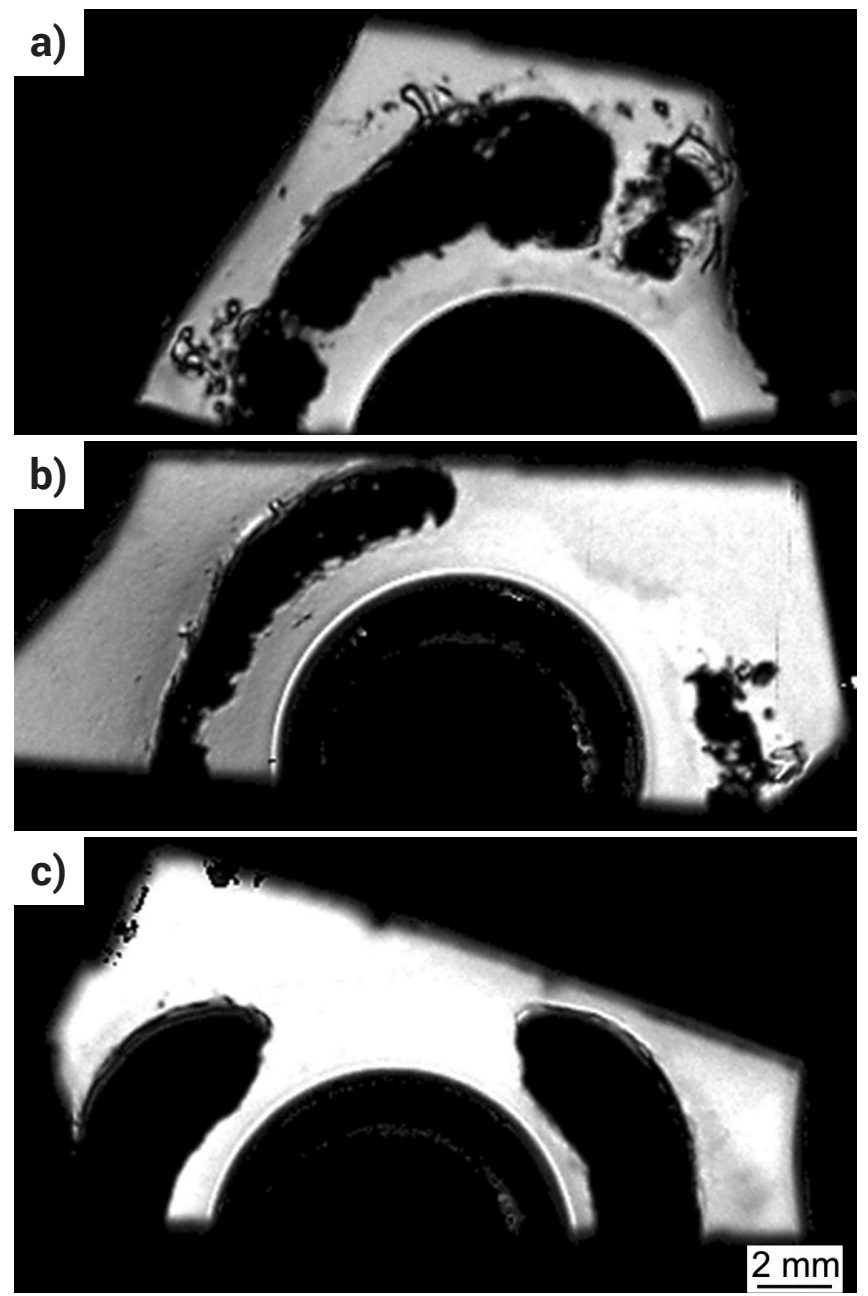

Rys. 6. Prezentacje C-skan złączy typu nakrętka-blacha wykonanych metodą MAG: a) łuk zwarciowy, b) puls, c) CMT

Fig. 6. C-scan presentation of nut-sheet MAG joints: a) short circuit, b) pulse, c) CMT

\section{Kontrola SAM połączeń spawanych wiązką lasera}

Badaniom poddano uproszczony mechanizm pochylenia oparcia (recliner) fotela samochodowego spawany laserem. Element złożony jest z dwóch części tj. płaskiej płyty oraz tarczy imitującej wieniec zębaty. W rozważanym przypadku badaniu poddano obszar o wymiarach 37 na 12 mm (rys. 7a) z krokiem skanowania $50 \mu \mathrm{m}$. W miejscu styku obu elementów (rys. 7b) występuje spoina czołowa.

Na rysunku 8 przedstawiono obraz typu C uzyskany podczas skanowania elementu z rysunku 7.

Na podstawie uzyskanych wyników można jednoznacznie wyróżnić strefę spoiny (kolor biały), obszar bez przetopu (kolor czarny), obszar poza próbką (ciemnoszary) oraz obszar rozproszenia fali ultradźwiękowej na krawędzi próbki (jasnoszary). Ponadto na rysunku 8 oznaczono miejsca przeznaczone do weryfikacji badaniami metalograficznymi. Dokonując pomiaru na podstawie obrazu C-skan można stwierdzić, iż głębokość wtopienia w miejscu podcięcia próbki wynosi $0,45 \mathrm{~mm}$, natomiast $w$ wybranym miejscu na obwodzie pomiar wykazał 1,9 mm. Porównując wyniki pomiarów na podstawie obrazów typu B-skan z wynikami badań metalograficznych $(0,5 \mathrm{~mm}$ w miejscu podcięcia, $1,8 \mathrm{~mm}$ poza tym obszarem) można stwierdzić, iż uzyskano wysoki stopień zgodności wyników. 

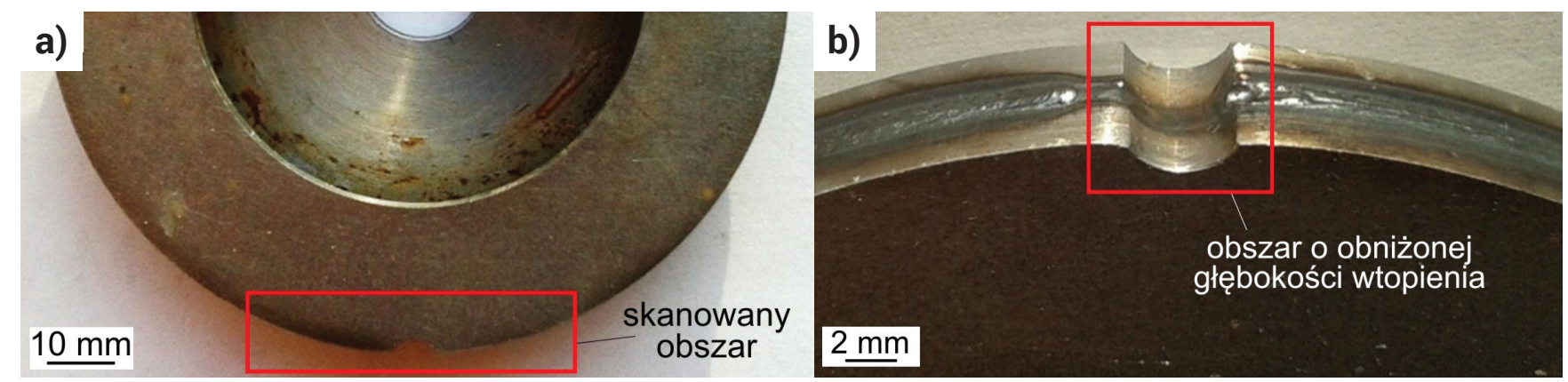

Rys. 7. Analizowany mechanizm pochylenia oparcia: a) skanowany obszar, b) miejsce o obniżonej głębokości wtopienia [12] Fig. 7. Analyzed recliner. a) scanned area, b) area with reduced depth of fusion [12]

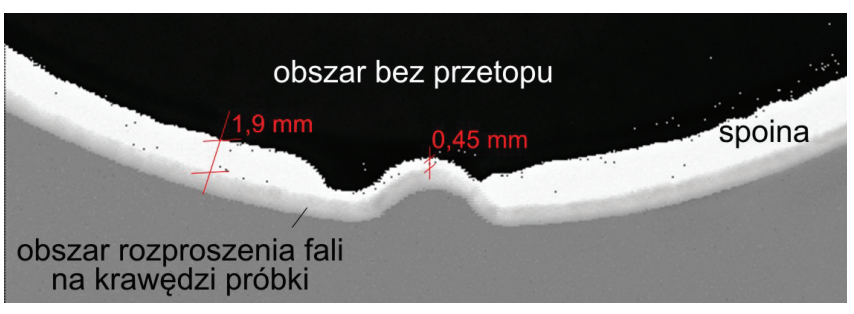

Rys. 8. Prezentacja C-skan z wyselekcjonowanymi obszarami złącza [12] Fig. 8. C-scan presentation with selected joint areas [12]

\section{Kontrola SAM połączeń zgrzewanych}

Na rysunku 9 przedstawiono prezentacje B- i C-skan dwóch złączy zgrzewanych punktowo, wykonanych z niestopowej głębokotłocznej stali DC04 o grubości 0,8 mm przy zastosowaniu różnych wartości natężenia prądu: 6,5 i 9,2 kA (pozostałe parametry: średnica robocza elektrody $5 \mathrm{~mm}$, czas zgrzewania $200 \mathrm{~ms}$ i siła docisku elektrod 1,8 kN).

$\mathrm{Na}$ podstawie analizy obrazów C-skan stwierdzono, że złącze wykonane na niższych parametrach prądowych wykazuje niezgodność w postaci przyklejenia (rys. 9a), na co wskazuje wyraźnie jaśniejszy obszar wewnątrz jądra, wynikający z większej amplitudy fali odbitej od niepełnego przetopu na powierzchni styku dwóch blach. Dla złącza wykonanego z użyciem wyższego natężenia prądu (rys. 9b) uzyskano pełny przetop na powierzchni styku, jednakże wewnątrz jądra zaobserwowano liczne niezgodności w postaci pęcherzy, które widoczne są również na przekroju w prezentacji typu B-skan.

\section{Pomiar SAM powierzchni zwilżania w połączeniach lutowanych}

Zastosowanie mikroskopii akustycznej nie ogranicza się tylko do detekcji niezgodności materiałowych. Technikę tę można wykorzystać jako skuteczne narzędzie pomiarowe, umożliwiające np. ilościową ocenę powierzchni zwilżonej lutem. Na rysunku 10 przedstawiono zakładkowe złącze lutowane ze stali niskostopowej z niewłaściwie przygotowaną powierzchnią (spoiwo - lut mosiężny). Pomiar prowadzono z obu stron połączenia ( $a, b$ - lustrzane prezentacje C-skan, c, d - obraz zbinearyzowany, umożliwiający pomiar powierzchni zwilżonej przez lut).

Oprogramowanie zaimplementowane w środowisko pracy wykorzystanego mikroskopu akustycznego umożliwia automatyczny pomiar powierzchni, której skala szarości spełnia zadane przez użytkownika kryteria (rys. 10b). Odpowiednio dobrane parametry: minimalny i maksymalny obszar pomiarowy o zadanych wartościach, tolerancje w skali szarości oraz algorytm uśredniania pozwalają na dokładną analizę wybranej powierzchni pomiarowej i archiwizację wyników w postaci cyfrowej.

\section{Kontrola SAM połączeń adhezyjnych}

Z uwagi na kilka rzędów mniejszą różnicę w impedancjach akustycznych stali i warstwy klejowej (np. w porównaniu z połączeniami lutowanymi czy spawanymi), detekcja obecności kleju i ewentualny pomiar powierzchni zwilżonej przez klej dla połączeń adhezyjnych są znacznie bardziej a)

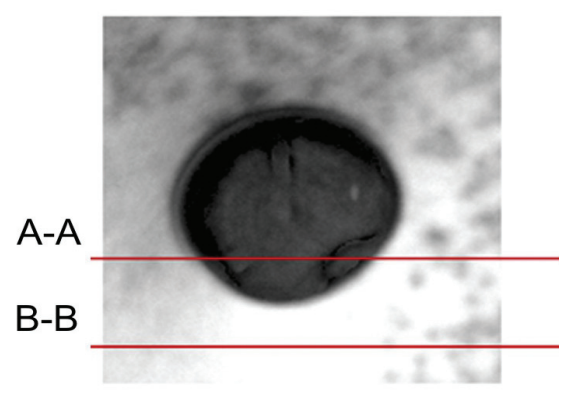

C-skan

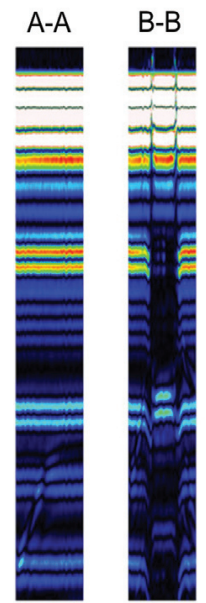

B-skan b)

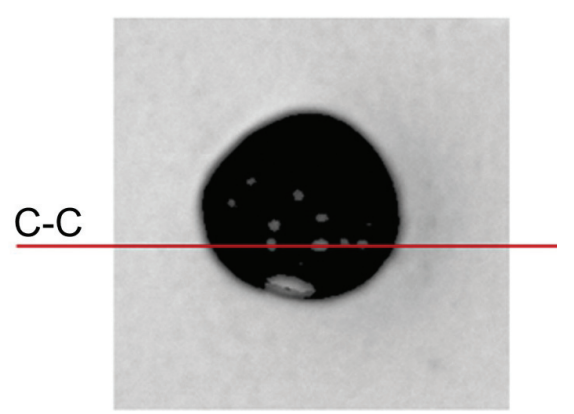

C-skan

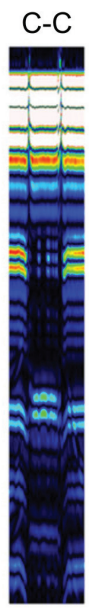

B-skan

Rys. 9. Wyniki badań ultradźwiękowych (C-skan i B-skan) złączy zgrzewanych punktowo: a) złącze z przyklejeniem, b) złącze z niezgodnościami w postaci pęcherzy

Fig. 9. Ultrasonic testing results (C-scan and B-scan) of spot welded joints: a) joint with incomplete fusion, b) joint with void 


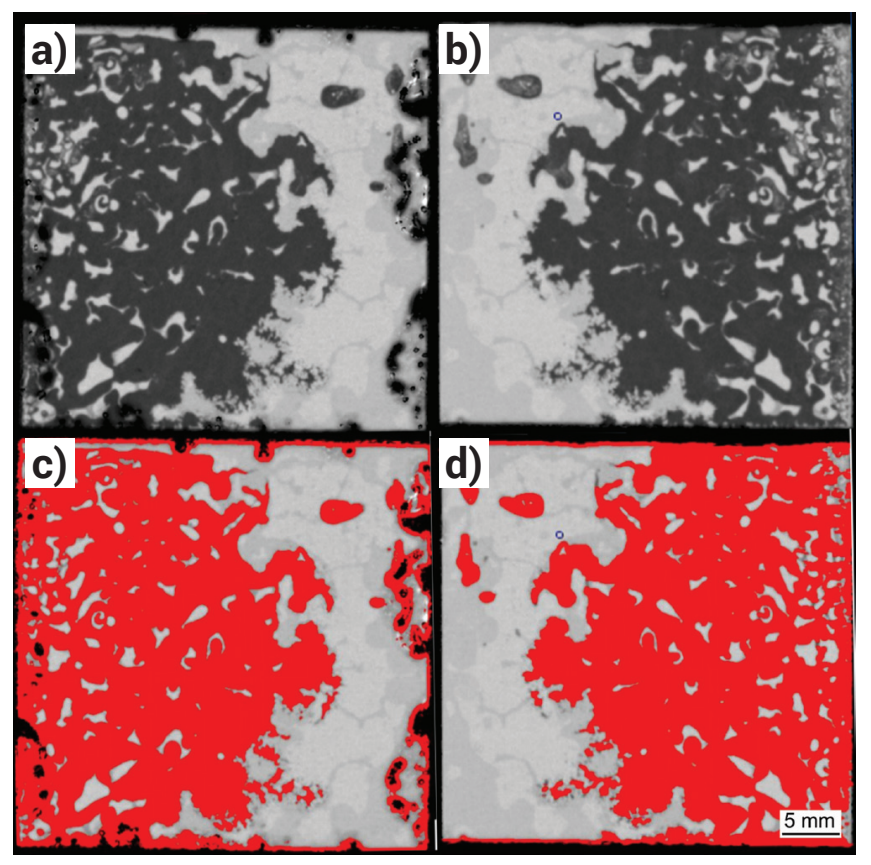

Rys. 10. Prezentacja C-skan złącza lutowanego $(a, b)$ oraz pomiar powierzchni zwilżonej $(\mathrm{c}, \mathrm{d})$

Fig. 10. C-scan presentation of brazed joint $(a, b)$ and wetted surface measurement $(c, d)$

problematyczne. Na rysunku 11 a przedstawiono surowy, nieprzetworzony cyfrowy obraz C-skan zakładkowego połączenia klejowego (stal niskostopowa łączona klejem epoksydowym, obszar skanowania wynosił 20x20 mm). Zwilżenie blachy przez warstwę kleju, podobnie jak dla połączeń lutowanych, uwidoczniona jest jako ciemniejszy obszar. Jest to spowodowane zmniejszeniem energii fali odbitej na granicy klej-blacha i jej częściowym przenikaniem do warstwy klejowej. Jednak z uwagi na znacznie mniejszą impedancję akustyczną warstwy klejowej (np. w porównaniu z lutem), kontrast pomiędzy zwilżoną częścią blachy, a częścią nieobejmującą kleju jest znacznie mniejszy. Zastosowanie zaawansowanych algorytmów przetwarzania sygnałów cyfrowych (rys. 11b) umożliwia poprawę kontrastu i wyraźne wyodrębnienie tych części konstrukcji, które wykazują kontakt z warstwą klejową. Przeprowadzenie operacji uśredniania, filtracji medianowej, progowania oraz operacji morfologicznych na obrazie (dylatacji oraz zamknięcia) umożliwia oszacowanie pola powierzchni zwilżonej przez klej. Kolorem czerwonym oznaczono obliczoną powierzchnię, która dla przykładu z rysunku 11c wynosi $241,55 \mathrm{~mm}^{2}$.
Należy podkreślić, że z uwagi na względnie niewielkie różnice sygnałów ultradźwiękowych pochodzących z obszarów adhezja-brak adhezji, kluczową kwestią podczas badania tego typu złączy, istotnie wpływającą na wynik pomiaru, jest stan powierzchni, do której doprowadzony jest impuls ultradźwiękowy. Wszelkie zanieczyszczenia, rysy oraz produkty korozji skutecznie maskują użyteczny sygnał, co uniemożliwia jego prawidłową interpretację.

\section{Kontrola SAM doczołowych złączy rurowych (zgrzewanie tarciowe, zgrzewanie łukiem wirującym)}

Zastąpienie osi posuwu osią obrotu umożliwia wykorzystanie mikroskopii akustycznej do oceny elementów osiowosymetrycznych, jak na przykład: rury, wały napędowe oraz półosie. Zastosowanie zaawansowanych algorytmów przetwarzania sygnałów umożliwia stworzenie przestrzennych prezentacji C-skan (rys. 12). Przedstawione wizualizacje stanowią wycinek pomiarowy wału napędowego zgrzewanego łukiem wirującym, w których kolor z palety RGB
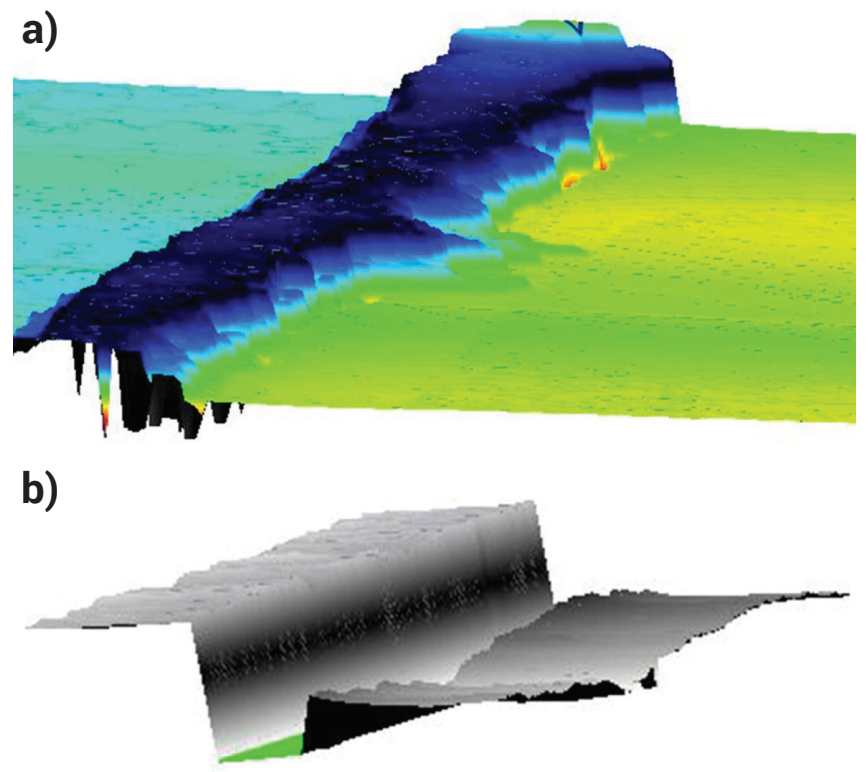

Rys. 12. Przestrzenne wizualizacje C-skan zgrzein wykonanych łukiem wirującym

Fig. 12. 3D visualization of C-scan MIAB welds

\section{a)}

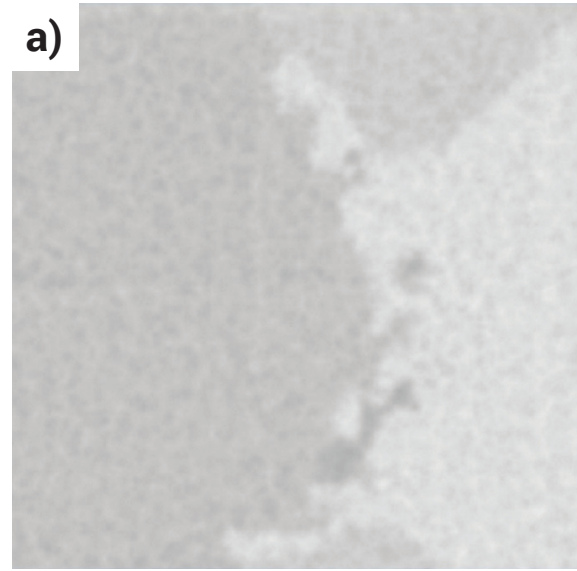

b)

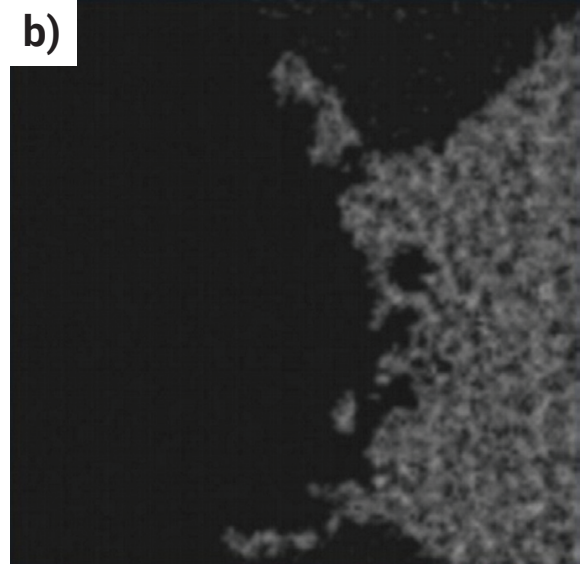

c)

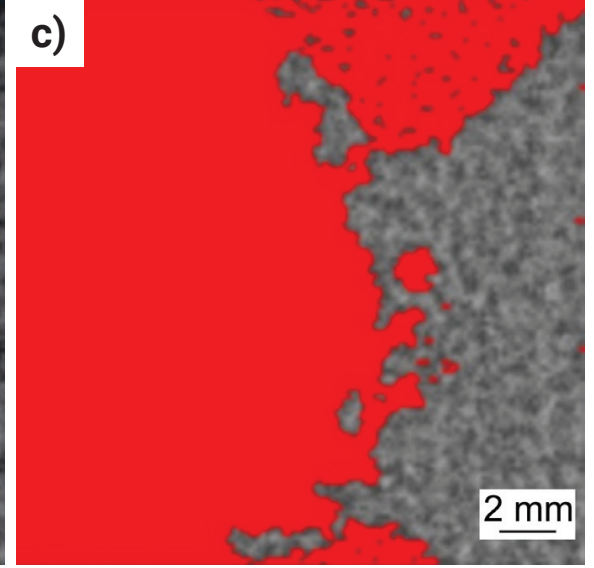

Rys. 11. Analiza SAM złącza klejowego: a) surowy obraz C-skan, b) obraz C-skan z poprawionym kontrastem, c) obliczona powierzchnia klejenia

Fig. 11. SAM Analysis of adhesive joint: a) raw C-scan image, b) C-scan image with improved contrast, c) calculated adhesive surface 
lub skali szarości odpowiadający czasowi przejścia fali (ToF ang. Time of Flight) jest reprezentowany w układzie kartezjańskim jako wymiar "z". Zastąpienie amplitudy fali czasem przejścia i jego wizualizacja w trójwymiarowej przestrzeni umożliwia pomiary geometryczne badanych komponentów: pomiar bicia, wysokość i szerokość wypływki, pomiar współosiowości. Na rysunku 12a przedstawiono wizualizację przestrzenną C-skan fragmentu zgrzeiny, która wyraźnie wskazuje na nieregularną wypływkę oraz różną średnicę elementów po obu stronach zgrzeiny. Rysunek 12b przedstawia wycinek zgrzeiny z niezgodnością w postaci wklęśnięcia powierzchni na obwodzie rury po prawej stronie wypływki. W tym przypadku z uwagi na duże rozpraszanie fali ultradźwiękowej na wypływce nie jest ona zwizualizowana.

\section{Badania SAM powłok natryskiwanych metodą Cold Spray}

Na rysunku 13 zaprezentowano prezentacje C-skan i trzy prezentacje B-skan powłok natryskiwanych niskociśnieniową metodą Cold Spray, dodatkowo przetopionych palnikiem TIG. Do procesu wykorzystano podłoże ze stopu aluminium $z$ grupy 5xxx. Proces natryskiwania przeprowadzono z wykorzystaniem czystego proszku Al oraz kompozytowej mieszaniny $\mathrm{Al}+60$ wag. $\% \mathrm{Al}_{2} \mathrm{O}_{3}$ (o granulacji $-50+10 \mu \mathrm{m}$ ). Wykonane powłoki charakteryzowały się relatywnie dużą grubością $(4 \div 5 \mathrm{~mm})$ i szerokością u podstawy ok. $6 \mathrm{~mm}$. Następnie wykorzystując palnik TIG przetopiono wykonane warstwy (natężenie prądu $55 \mathrm{~A}$, natężenie przepływu Ar $11 \mathrm{l} / \mathrm{min}$, odległość wierzchołka elektrody od powierzchni powłoki utrzymywana była na napięcie łuku elektrycznego 20 V) i dokonano ultradźwiękowej oceny granicy podłoże - przetopiona warstwa. W wyniku przeprowadzonych analiz stwierdzono, że mimo przetopienia, na granicy powłoki wykonanej z użyciem mieszaniny $\mathrm{Al}+\mathrm{Al}_{2} \mathrm{O}_{3}$, a podłożem występuje wyraźna granica. Jest ona spowodowana aglomeracją korundu i jego grawitacyjnym opadaniem na granicę powłoka - podłoże podczas przetapiania. Z uwagi na różnice we właściwościach akustycznych ceramiki $\left(\mathrm{Al}_{2} \mathrm{O}_{3}\right)$ i podłoża (stop Al serii $5 x x x)$ zauważalne jest wyraźne odbicie na granicy tych ośrodków, uwidocznione w postaci jasnego koloru. Dla powłoki wykonanej z czystego proszku aluminiowego wystąpił pełny przetop powłoki i jej wtopienie w podłoże (kolor czarny).
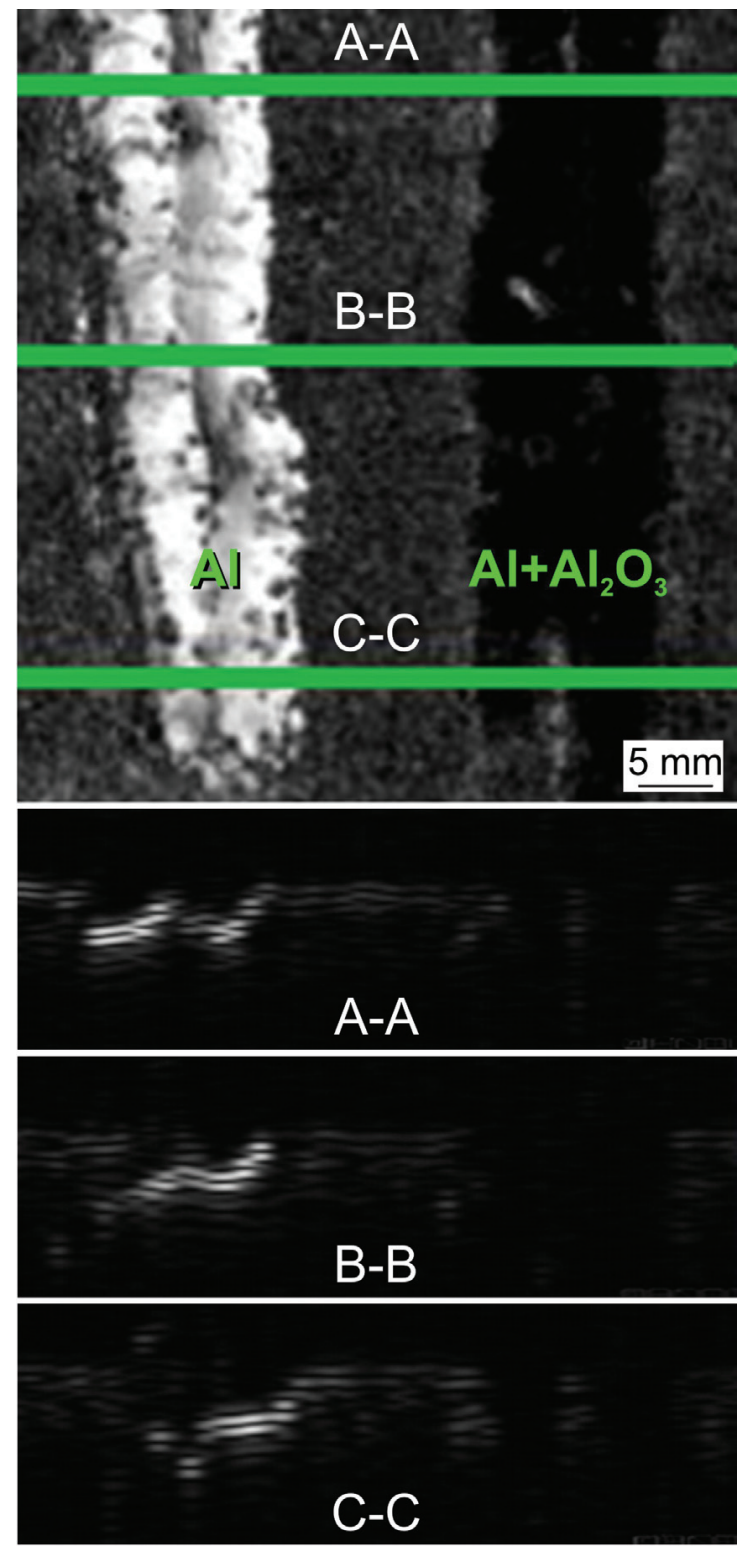

Rys. 13. Prezentacja C-skan (góra) i B-skan w wybranych przekrojach powłok naniesionych metodą Cold Spray, przetopionych łukiem elektrycznym metodą TIG [13]

Fig. 13. C-scan presentation (top) and B-scan in selected cross sections of coatings applied with Cold Spray method, TIG remelted [13]

\section{Podsumowanie}

Przeprowadzone badania wskazują, że skaningowa mikroskopia akustyczna stanowi skuteczne narzędzie kontrolne umożliwiające detekcję niezgodności, jak również pomiar pola łączenia, w złączach spajanych. Wyniki wizualizowane w postaci prezentacji typu B-skan w wybranych przekrojach prostopadłych do powierzchni z uwidocznionymi nieciągłościami mogą w pewnych warunkach stanowić alternatywę w stosunku do zgładów metalograficznych. Z uwagi na wysoki stopień automatyzacji uzyskane wyniki są obiektywne i powtarzalne. Współczesne techniki ultradźwiękowe wykorzystywane do oceny jakości złączy spajanych w większości przypadków znajdują zastosowanie do badań konstrukcji o grubości ścianek przekraczających $5 \mathrm{~mm}$. Zaprezentowane przykłady wskazują, że skaningowa mikroskopia akustyczna może stanowić doskonałe uzupełnienie istniejących narzędzi dla złączy cienkościennych, a jej spektrum zastosowań obejmuje szeroką gamę złączy. Niezależnie od mechanizmu wiązania (adhezja, dyfuzja, przetop, zakleszczanie mechaniczne) metoda ta pozwala uzyskać precyzyjne wyniki bez konieczności niszczenia próbki. 


\section{Literatura}

[1] R. Kaczmarek, K. Kaczmarek, J. Słania, R. Krawczyk: Wykonywanie badań ultradźwiękowych techniką TOFD w aspekcie wymagań norm przedmiotowych, Biuletyn Instytutu Spawalnictwa, nr 6, s. 58-63, 2016.

[2] P. R. Hoskins, K. Martin, A. Thrush: Diagnostic Ultrasound: Physics and Equipment, Cambridge University Press, 2010.

[3] Y. Jing, K. Hak-Joon, S. Sung-Jin, K. Sung-Sik, K. Kyungcho, S. Myung-Ho: Model-based simulation of focused beam fields produced by a phased array ultrasonic transducer in dissimilar metal welds, NDT \& E International, vol. 44, issue 3, pp. 290-296, 2011.

[4] https://www.olympus-ims.com

[5] G. Maev: Acoustic Microscopy. Fundamentals and Applications, Weinheim: Wiley-VCH Verlag GmbH \& Co. KGaA, 2008.

[6] A. Briggs, Kolosov O.: Acoustic Microscopy, Oxford: Oxford University Press, 2010.

[7] T. Kundu: Ultrasonic Nondestructive Evaluation: Engineering and Biological Material Characterization, CRC Press, 2004

[8] R.J.M. da Fonseca, L. Ferdj-Allah, G. Despaux, A. Boudour, L. Robert, J. Attal: Scanning Acoustic Microscopy-recent applications in materials science, Advanced Materials, vol. 5 (7-8), pp. 508-519, 1993
[9] H-T. Lee, M. Wang, R. Maev, E. Maeva: A study on using scanning acoustic microscopy and neural network techniques to evaluate the quality of resistance spot welding, The International Journal of Advanced Manufacturing Technology, vol. 22 (9-10), pp. 727-732, 2003.

[10] K.Kawashimaa, M.Muraseb, R. Yamadac, M. Matsushimad, M. Uematsue, F. Fujitaf: Nonlinear ultrasonic imaging of imperfectly bonded interfaces, Ultrasonics, vol. 44, pp. 1329-1333, 2006.

[11] M. Korzeniowski, B. Białobrzeska: Analysis of using acoustic microscopy to evaluate defects in spot welding joints, Archives of Metallurgy and Materials, vol. 61, pp. 1009-1019, 2016.

[12] P. Kustroń, M. Korzeniowski: Badania połączeń spawanych laserem z zastosowaniem mikroskopii akustycznej, Przegląd Spawalnictwa, vol 87 (8), s. $21-23,2015$.

[13] A. Małachowska, T. Piwowarczyk, M. Winnicki, M. Stachowicz, M. Korzeniowski: Preliminary studies of welding possibility of low pressure cold sprayed coatings, poster, 70th IIW Annual Assembly \& International Conference, Shanghai China, 2017. 